\title{
Como abordar a urbanização popular? Uma incursão nas práticas, lutas e conquistas em um bairro popular da cidade de Mar del Plata, Argentina
}

How to approach popular urbanization? An incursion in the practices, struggles and conquests in a popular neighborhood of Mar del Plata city, Argentina

Lucia Antonela Mitidieri [a] (1)

[a] Universidad Nacional de Mar del Plata (UNMdP), Instituto de Investigación en Desarrollo Urbano, Tecnología y Vivienda, Faculdade de Arquitectura, Urbanismo y Diseño, Mar del Plata, Buenos Aires, Argentina.

Como citar: Mitidieri, L. A. (2020). Como abordar a urbanização popular? Uma incursão nas práticas, lutas e conquistas num bairro popular da cidade de Mar del Plata, Argentina. urbe. Revista Brasileira de Gestão Urbana, 12, e20190292. https://doi.org/10.1590/2175-3369.012.e20190292

\section{Resumo}

As abordagens tradicionais sobre os processos e práticas de urbanização popular encontram-se permeadas de olhares hegemônicos, em que a principal figura urbanizadora é o Estado. A ausência deste acaba gerando uma visão reduzida e homogênea nas análises e nos diagnósticos, sinalizando única e exclusivamente o déficit de urbanização e a precariedade desses territórios. A necessidade de pensar criticamente esses processos diacrônicos, permeados por tensões, lutas e conquistas, além de múltiplos atores, leva a conceber outras aproximações possíveis. Assim, o presente trabalho tem o objetivo de abordar a urbanização popular de uma perspectiva teórico-crítica e axiológica, abrindo o diálogo com os saberes e as potencialidades que esses territórios possuem. Numa ordem empírica, será analisado um bairro popular localizado na cidade de Mar del Plata, Argentina. Os resultados foram obtidos com uma metodologia qualitativa, com base em entrevistas, observação participante e registro fotográfico. A conclusão revela que é possível entender a urbanização popular como uma manifestação autônoma, e não um mero preenchimento das lacunas deixadas pela ausência do Estado ou a falta de interesse do capital.

Palavras-chave: Saberes locais. Bairro popular. Autogestão. Autoconstrução.

\section{Abstract}

The traditional approaches to the processes and practices of popular urbanization are permeated by hegemonic viewpoints, in which the main urbanizing figure is the State. In the absence of this, it ends up generating a reduced and homogeneous analysis and diagnostics, signalizing only and exclusively for the urbanization deficit and precariousness of this territory. A need to think critically about these diachronic processes, permeated by tensions, struggles, and conquests, beyond multiple actors, led to granting other approximations. Thus, the present work has as objective to approach popular urbanization from a theoretical-critical and axiological perspective, opening the dialogue with the knowledge and potentialities that these territories possess. In an empirical order, a popular neighborhood, located in Mar del Plata city, Argentina will be analyzed. The results were obtained with a qualitative methodology, based 
on interviews, participant observation, and photographic records. The conclusion reveals that it is possible to understand popular urbanization as an autonomous manifestation and not merely a filling in of the gaps left by the absence of the State or the lack of interest by the capital.

Keywords: Local knowledge. Popular neighborhood. Self-management. Self-construction.

\section{Introdução}

Primeiro, devemos produzir uma visão do que é cada comunidade no singular, como é produzida e reproduzida a relação com o território e a terra, o comércio e a escola, e só podemos pensar em formas de relacionamento que cada uma delas forjou ao longo da sua história, com os espaços que não controla: o estado e o mercado${ }^{1}$. (Cusicanqui, 2018, p. 115).

O conceito de urbanização popular carece de uma definição teórico-crítica e axiológica. Geralmente, ouvimos falar de urbanização de favelas, urbanização de assentamentos precários e, na maioria dos casos, essas abordagens encontram-se permeadas de olhares hegemônicos em que a figura urbanizadora é o Estado. Essa visão acaba sendo também homogênea pela sinalização única e exclusiva para o déficit de urbanização/precariedade desses espaços ${ }^{2}$. Na literatura acadêmica, portanto, há poucos estudos que abordam a urbanização popular utilizando esse mesmo conceito. Alguns pesquisadores preferem "falar" de produção social do hábitat ou hábitat informal ${ }^{3}$, enquanto outros autores citados a seguir entendem a urbanização popular como uma prática produzida num hábitat e por um setor popular, onde as irregularidades são a norma para a produção de moradia e serviços, geridos ou construídos por fora da lógica do mercado e sem apoio do Estado.

Connolly (2013) se refere ao "urbanismo popular" como uma prática (hábitat popular) constituída pela população sem apoio do Estado e fora da lógica do mercado. Isso quer dizer que, ainda que exista um mercado de compra de terras, materiais de construção, contratação de mão de obra etc., não se constrói para vender e trata-se de uma produção desenvolvida sem o apoio de profissionais e sem cumprir o quadro legal territorial (urbano e ambiental).

Sob uma perspectiva similar, Pirez (2018) define a urbanização popular como um conjunto de ações resultante de práticas populares, predominantemente produzidas por fora dos mecanismos comerciais e do Estado. Na maioria das vezes, tem como produto (resultado de processos temporais muito longos e penosos) uma urbanização precária, de baixa qualidade, que implica o desenvolvimento de capacidades solidárias (familiares e sociais) para a subsistência. Ao relacionar a urbanização popular com os setores populares, ainda segundo Pirez (2018), é possível percebê-la como parte da construção de alternativas às suas condições de fragilidade e subordinação, devido à ausência do direito de acessar uma localização urbana de qualidade.

As variáveis nessas definições são autoconstrução, irregularidade, o rol do Estado (por ausência) e do mercado (por fora) - quesitos nebulosos e polissêmicos. Contudo, algumas questões ainda não são respondidas nas definições que a literatura citada nos oferece. Teorias e visões homogêneas ou muito encaixadas na lógica sincrônica dos modos de produção esquecem que por trás dos processos diacrônicos de urbanização popular existem lutas e conquistas, conflitos e tensões (Holston, 2013; Zibechi, 2015).

Assim sendo, o presente artigo parte dos seguintes questionamentos: como pensar a urbanização popular desde as potencialidades desses territórios? Como compreender o papel das lutas, conflitos e disputas, práticas intrínsecas a esses processos?

\footnotetext{
${ }^{1}$ Todas as citações textuais em outro idioma foram traduzidas ao português pela autora, para facilitar a leitura.

${ }^{2}$ Algumas pesquisas que tratam deste tema desde o déficit e a precariedade são: Rodulfo (2007), Abiko \& Coelho (2009), Marques (2010), Denaldi (2013), Cardoso (2016).

${ }^{3}$ Dezessete pesquisadores latino-americanos reuniram os seus trabalhos em um livro intitulado El camino posible: producción social del hábitat en América Latina, publicado em 2012 e disponível em Habitat International Coalition (2019). Outros autores, como Nora Clichevsky (2000), pesquisam há bastante tempo o "hábitat informal".
} 
Em vista disso, será abordado um eixo de reflexão conceitual segundo uma revisão bibliográfica que pretende trazer olhares complementares e também opostos para analisar questões como a ocupação de terras, o rol do Estado, a autoconstrução da moradia e a autogestão dos serviços e equipamentos urbanos. Assim, na primeira sessão deste artigo, pretende-se debater a partir da indagação: como (também) se constrói cidade?

Na ordem das práticas, a premissa de achar uma forma de olhar desde a urbanização popular e não para ela se materializa com a análise dos processos e das práticas no bairro Nuevo Golf, localizado na cidade de Mar del Plata, Argentina. Das 114 "villas e assentamentos precários" da cidade, este se configura como o maior assentamento no em 2017 - pela quantidade populacional e pela extensão territorial. Esse território permitiu observar uma experiência interessante no que respeita às lutas e às conquistas em torno da urbanização popular, pela atuação política de atores relevantes. A "voz" do presidente da associação de moradores, Mario Peralta, concedida por meio de entrevista semiestruturada foi a principal fonte de informações. Também foram utilizadas informações secundárias, como matérias jornalísticas, relatórios municipais e de ONGs. 0 registro fotográfico, em sequências temporais, permite visualizar o desenvolvimento dos diversos processos.

\section{Como (também) se constrói cidade?}

Que destino as migalhas humanas têm? O mundo as convida a desaparecer, diz: "Você não existe, porque você não merece existir". A realidade oficial tenta escondê-las ou perdê-las: é chamada 'cidade escondida' à população marginal que mais cresceu no Buenos Aires, e são chamadas 'cidades perdidas' os bairros de lata e papelão que brotam nos morros e lixões da Cidade do México. (Galeano, 1998, p. 61).

\section{A terra enquanto disputa e posse}

Nas cidades, o hábitat "ilegal", "irregular", "informal” implica duas formas de transgressões: a primeira é baseada na falta de títulos de propriedade (ou contratos de aluguel); a segunda, no descumprimento dos padrões de construção da cidade. Cada um deles se materializa em diferentes categorias de informalidade, segundo Clichevsky (2000). Nesse debate, a terra cumpre um papel fundamental enquanto disputa e posse. 0 processo de ocupação da terra urbana como mecanismo de sobrevivência ante as condições de exclusão mencionadas anteriormente é caracterizado pela extensa literatura como invasões ilegais ${ }^{4}$ da propriedade (privada ou pública). Na herança funcionalista, tudo o que foge da situação de ordem e controle é considerado irregular e/ou ilegal e assume uma conotação negativa (Costa, 2008). Maricato (2000, p. 154) sustenta que "[...] esta gigantesca ilegalidade não é fruto da ação de lideranças subversivas que querem afrontar a lei. É resultado de um processo de urbanização que segrega e exclui". Ainda que o termo "invasões" seja — juridicamente — correto, no Brasil, movimentos com origem nas lutas rurais contra os grandes latifúndios (os quais lutam por um lugar onde morar) utilizam o termo "ocupação". Isto é, ação que promove o uso social da terra. Da mesma forma, a legislação urbanística (Estatuto da Cidade, Lei no 10.257, de 2001) (Brasil, 2001) regulamenta o uso da propriedade urbana em prol do bem coletivo, da segurança e do bem-estar dos cidadãos. Segundo (Informação verbal, 15 de outubro de 2017) uma liderança do Movimento de Luta por Moradia (MLM), “[...] a gente não invade, quem invade é o sistema. A gente ocupa". Deste modo, daqui por diante, será utilizado o termo ocupação para toda ação que busque romper com o processo de urbanização excludente. Esta que é caracterizada pela ausência de políticas sociais, completamente estrutural, que se sustenta sobre a estrutura fundiária arcaica (Maricato, 2000) e como a manutenção do colonialismo que os nossos países latino-americanos experimentam.

\footnotetext{
${ }^{4}$ Cf. Davis (2006), Cardoso (2016).
} 
Atualmente, ocupações se produzem predominantemente em terra urbana de baixo valor, em lugares de risco ambiental e em encostas de morros (Davis, 2006). Terras ignoradas pelo mercado - como pântanos, mananciais, depósitos de lixo, locais contaminados ou sujeitos a inundações - as quais acabam sendo ocupadas por aqueles que não conseguem adentrar pela lógica "formal e/ou legal" o acesso à moradia.

Além das ocupações ilegais, há um processo de urbanização irregular, não necessariamente ilegal, que ocorre de modo paralelo. Esse processo funciona por meio de um mercado imobiliário invisível e informal, que, nas palavras de Davis (2006, p. 50), trata-se de uma "privatização das invasões". Geralmente, há por trás de cada loteamento irregular um mercado imobiliário especulativo que não pode ser considerado estritamente ilegal. Mas, em contrapartida, pode apresentar diversas formas de ilegalidade em relação às exigências urbanísticas, padrões de fornecimento de serviços ou à documentação de propriedade (Maricato, 2000; Davis, 2006). Famílias de baixa, média-baixa ou média renda compram lotes de empresários e obtêm um título de posse do terreno, de fato ou de direito, embora as casas que ali se constroem nem sempre tenham autorização formal.

A posse da terra origina um debate entre dicotomias: a construção da matriz de segurança-insegurança que o planejamento e a regulação fundiária engendram. Rolnik (2015), no seu livro Guerra dos lugares, a colonização da terra e da moradia na era das finanças, analisa, em inúmeros exemplos, as variadas formas em que grupos ou indivíduos experimentam a não seguridade da posse do lugar onde moram, atravessadas por uma trama jurídico-administrativa que inclui-exclui e mecanismos por meio dos quais se constroem-destroem os espaços que, de uma forma ou outra, lhes pertencem. Segundo Rolnik (2015, p. 152), "[...] uma questão de economia política-leis, instituições e processos de decisão relacionados ao acesso e ao uso da moradia e da terra são atravessados pelas estruturas de poder existentes na sociedade".

\section{A propriedade privada e o papel do Estado}

Por outro lado, a propriedade privada é um dos tópicos que atravessam a narrativa da política pública que pretende combater a pobreza pelo mecanismo de regulação da posse da terra. Nesse sentido, existem posições antagônicas sobre o papel da propriedade privada.

A pesquisa etnográfica proposta pelo antropólogo James Holston (2013), no seu livro Cidadania insurgente, disjunções da democracia e da modernidade no Brasil, revela processos, mecanismos e práticas da cidadania brasileira e analisa o sistema de distribuição de terras no país. Segundo o autor, desde o período colonial, este foi feito sobre exceções e irregularidades legais imensas, o que levou as elites a conseguir a legalidade de suas grandes porções de terra com base em falsos arranjos. No entanto, os mais pobres sempre foram estigmatizados e criminalizados pela ocupação ilegal da terra, sendo essa a forma de obtê-la que ainda se pratica. As condições ilegais dos loteamentos (como negócio) tornaram a terra acessível aos brasileiros pobres, viabilizando o sonho da casa própria (que vendiam dentro desse negócio) e o sonho da propriedade privada, não obstante muitas injustiças sejam cometidas ao redor desses ideais. Os casos estudados pelo autor, localizados na periferia leste da cidade de São Paulo (Jardim das Camélias, Lar Nacional), mostram o engano que os moradores experimentaram ao comprar seus lotes em transações ilegais, sujeitos depois a processos de reintegração de posse. A luta pela propriedade privada que os cidadãos empreenderam, fazendo uso de seus direitos como contribuintes, é uma das mais importantes conquistas que pretendem alcançar.

Sob outro ponto de vista, Raquel Rolnik (2015) ajuda a compreender como as exceções vão se manifestando na cidade, assinalando o papel central da regulação urbanística. Experiências ao redor do mundo (Maldivas, Ruanda, Camboja, Indonésia) mostram o paradoxo que existe nos programas de reforma fundiária. A lógica para combater a pobreza seria o registro e a titulação da terra. Com base nisso, converteria em mercadoria que os pobres poderiam utilizar para sair da sua situação de pobreza. No entanto, Rolnik (2015) demonstra que não há evidências sobre os resultados econômicos de 
programas de titulação. Na verdade, estes não fazem mais do que intensificar a situação de vulnerabilidade em que se encontram. A estratégia, tanto no processo de reforma fundiária como no de titulação, é a utilização desses programas como poderosos mecanismos que seguem duas diretrizes. Por um lado, a finalidade é "converter" as terras desvalorizadas em ativos de livre circulação no mercado e, por outro, impor a hegemonia da propriedade privada com a insegurança da posse como modelo perpetuador da exclusão territorial (Rolnik, 2015).

Os questionamentos que a autora coloca - quem se beneficia? (Rolnik, 2015, p. 211); aumenta a segurança de posse? (Rolnik, 2015, p. 214); melhora a qualidade de vida nesses assentamentos? (Rolnik, 2015, p. 215) - dão alguns subsídios para pensar a quem realmente favorece a segurança da posse, tida como elemento essencial da proteção da vida e dignidade humanas. A propriedade individual registrada acaba sendo um veículo de investimento capaz de maximizar seu valor e diminuir custos de transação, o que, ao mesmo tempo, gera "[...] poderosos mecanismos para eliminar formas de relação com a terra e a moradia [...]" (Rolnik, 2015, p. 202).

Uma forma de trazer novos entendimentos nos complexos processos de urbanização que flutuam entre a legitimidade e a ilegalidade é compreender a informalidade como um modo de urbanização e o papel que o Estado ocupa nesses modos de fazer cidade (Roy, 2005).

Como mencionado, mercados ilegais, processos de ocupação da terra, assim como a coexistência de loteamentos fechados nas periferias, se configuram como um complexo continuum de legalidade e ilegalidade. Segundo o raciocínio de Anarya Roy (2005), o planejamento urbano e o aparato legal do Estado têm o poder de determinar o que é informal e o que não é, assim como de construir e reconstruir categorias de legitimidade e ilegitimidade. De acordo com as conjunturas políticas, o clientelismo do Estado nesses processos não pode ser subestimado, já que este pode ser acionado como potente moeda político-eleitoral ativada ante as demandas populares (Clichevsky, 2000; Rolnik, 2015). A formação (enquanto permissão) e a consolidação (enquanto urbanização) dos bairros populares são completamente funcionais às estratégias destes, os quais, segundo Zibechi $(2006,2015)$, se encontram completamente dominados pelo mercado. Para o autor, a crise de autonomia que o Estado está sofrendo o coloca numa posição de subordinação tal que seu papel acaba sendo orientado aos interesses do mercado em detrimento do bem comum.

Retomando Rolnik (2015), por trás da figura de um Estado benevolente que facilita processos de regulação ou gerando investimento em infraestrutura e serviços, muitas vezes as consequências são a reafirmação da transitoriedade permanente e o estigma territorial.

\section{O "auto" como resistência e forma de acesso às negações}

Forças de expulsão, exclusão, crises e dominações consolidaram um padrão de urbanização popular baseado na autoconstrução da moradia e, em alguns casos, na autogestão dos serviços urbanos, de atividades culturais, educativas, esportivas e recreativas. Em geral, esses processos de hábitat e moradia popular são levados adiante por esforços de autogestão de recursos, por práticas e estratégias coletivas, tanto de acesso à terra e à moradia quanto à infraestrutura de serviços fora das condições "formais". A expansão periférica que essa autoconstrução possibilita constitui um paradoxo espacial: cada instância de autoconstrução reproduz a periferia (Holston, 2013). Quer dizer:

[...] na medida que os autoconstrutores transformam as suas casas e urbanizam os seus bairros, essas melhoras produzem um deslocamento para novas áreas cada vez mais distantes, e por tanto, de transformação e reprodução das condições de pobreza e precariedade constante. (Holston, 2013, p. 221).

Autores como Pradilla Cobos (1987) e Oliveira (2006) preferem não romantizar o "[...] lento e doloroso processo de autoconstruir a moradia [...]" (Pradilla Cobos, 1987, p. 52), já que a aceitação desse cenário comum nas nossas cidades supõe que a maior parte da força de trabalho para construir essas moradias esteja desempregada ou subempregada e possa, portanto, utilizar as horas de folga para 
construir a própria habitação e depender da capacidade e força da sua luta para obter a instalação de algum tipo de serviços. A autoconstrução é compreendida por eles como um modo de rebaixar o custo de reprodução da força de trabalho que, no final, não tem valor de troca, apenas valor de uso, devido ao custo de uma habitação popular ser basicamente a força de trabalho do futuro proprietário.

Seguindo o mesmo raciocínio, Pirez (2015) argumenta a importância dos serviços urbanos como condições - e condicionantes - de reprodução social urbana. Estes se configuram como atividades necessárias para a reprodução dos processos de acumulação de capital e atuam como satisfatórios (componentes de integrações social e territorial). A sua satisfação depende da localização da população na cidade, das condições que se estabelecem para sua produção e consumo (situações econômica, social e cultural) e da resposta do Estado ante essa necessidade. Desde o momento em que essa demanda não é satisfeita, os serviços são produzidos ou consumidos informalmente (Pirez, 2015).

A partir dessa análise, Pirez (2015) define a urbanização popular baseado em parâmetros que se incluem dentro da lógica capitalista. Ele argumenta que os processos de acesso aos bens e serviços são feitos, nesses territórios, fora da lógica da acumulação e sob uma tríade contraditória entre direitos, demandas e autoprodução:

A urbanização popular é uma forma organizada pela lógica da necessidade. É produzida para atender à necessidade de ativos urbanos da população que não tem acesso mercantil e pode ser redistributiva, quando existem políticas estaduais que contribuem para seu financiamento ou fornecem recursos significativos, e não redistributiva, quando se baseia em recursos populares e, particularmente, no trabalho desses grupos. (Pirez, 2015, p. 61).

Seguindo essa lógica, a exclusão dos serviços urbanos implica a consolidação das desigualdades sociais no uso da cidade - que se fortalece ainda mais com a mercantilização deles. Ainda que nem todos os serviços possam ser adquiridos por processos informais de produção, "[...] a urbanização popular os incluiu em processos que permitiam o acesso não comercial com base no esforço econômico e nas horas de trabalho dos mesmos usuários necessitados, geralmente sem expandir a redistribuição [...]" (Pirez, 2015, p. 67).

Sob outra perspectiva, autores como Holston (2013) e Zibechi (2015) destacam o desenvolvimento de novas identidades culturais e formas de ocupação e distribuição do espaço urbano nesses processos de resistência coletiva. Holston (2013) defende a ideia de que a ocupação massiva dos territórios da periferia trouxe uma nova perspectiva para a cidadania brasileira. 0 autor afirma: "Como acontece com a maior parte das questões de dominação, a periferia também denota lutas e, para muitos moradores, realizações individuais e coletivas sem precedentes" (Holston, 2013, p. 208). 0 processo de assentamento em bairros longe das prestações de serviços e trabalho, com infraestrutura inexistente, violência e expulsões, entre outras das características, por mais dramático que seja, constitui o inegável paradoxo entre essas questões e o heroísmo de dominação e redefinição. As melhorias que gradualmente se visualizam nos bairros ao se consolidar, por mínimas que sejam, constituem grandes avanços nas suas lutas batalhadas cotidianamente. Esses projetos alternativos de cidadania que reformulam o desenvolvimento do Estado e a sua relação com os cidadãos constituem, segundo o autor, a "irrupção de uma cidadania insurgente" (Holston, 2013, p. 260).

Zibechi (2015) vai um pouco mais além, ao afirmar que se inaugura outra etapa política nos novos espaços autoconstruídos — são lugares onde nascem novas formas de poder popular: "[...] da sobrevivência e resistência, passou-se para a impugnação da sociedade hegemônica [...]" (Zibechi, 2015, p. 57). Nesses espaços a lógica estatal aparece subordinada à lógica comunitário-popular, em que as relações assentadas em valores de troca, patriarcais e hierárquicas, se substituem por relações baseadas nos afetos, e as mulheres-mães adquirem um papel central:

O predomínio dos valores de uso, ou melhor, a destruição dos valores de troca em valores de uso aparece estreitamente ligado ao 'auto' e ambos estão relacionados com o papel destacado das mulheres. Uma lógica doméstica, espaço onde por certo tempo esteve confinada a produção de valores de uso, começou a se expandir para o espaço público, a se propagar de modo capilar pelo 
tecido social, de modo particular nos momentos críticos para a sobrevivência das comunidades. (Zibechi, 2015, p. 46).

A autogestão e a autoconstrução colocam não somente a questão de construir a moradia, senão também a geração de novos espaços controlados e reformulados pela própria população, com mulheres e jovens adquirindo protagonismo, criando contra poderes assentados em seus bairros-territórios. 0 autor aponta que é uma conjuntura relativamente nova que começa, aproximadamente, nos anos 1980, quando a "recolonização neoliberal" avança no continente sul-americano em um ataque às formas de vida dos setores populares, sublinhando o caso da ditadura de Pinochet, no Chile, como primeiro experimento neoliberal (Zibechi, 2015, p. 57).

Roy (2005) reconhece a importância da prestação estatal de infraestrutura, mas indica que o seu fornecimento e sua distribuição não são questões técnicas, e sim um processo político. Os modelos hegemônicos de especialização são perturbados por um conjunto diferente de especialistas que possuem outro tipo de conhecimentos: os residentes de assentamentos. Alguns movimentos também têm conquistado a autonomia alimentar mediante formas de produção agrícola.

Nesse sentido, os exemplos colocados por Zibechi (2006), como os quase 5 mil refeitórios populares em Lima, as múltiplas escolas autogovernadas pelos Sem Terra no Brasil ou as mais de 170 fábricas recuperadas na Argentina afirmam, segundo o autor, a passagem de formas de ação instrumental para formas autoafirmativas, em que o "auto" pressupõe uma expansão de capacidades.

\section{Práticas e atores no processo de urbanização popular do bairro Nuevo Golf, Mar del Plata, Argentina}

Localizado na cidade média de Mar del Plata (Figura 1), o bairro Nuevo Golf é caracterizado, segundo os parâmetros da Lei no 14.449 da Província de Buenos Aires de acesso justo ao hábitat (Argentina, 2013), como um "assentamento precário", sendo o mais populoso da cidade com aproximadamente mil famílias. As características do bairro são comumente apresentadas pelos relatórios municipais/estaduais ou em demais pesquisas, com um olhar reduzido a aspectos estruturais e físicos. Da mesma forma, características técnicas e de construção de moradias apresentam problemas do ponto de vista da superlotação, da segurança das edificações e da falta geral de instalações sanitárias, entre outros. Essas ausências são parte da realidade territorial e não podem ser desconsideradas no momento de produzir uma análise. Entretanto, é preciso considerar essas questões estruturais tanto como outras características e potencialidades - como a autogestão, por exemplo. 


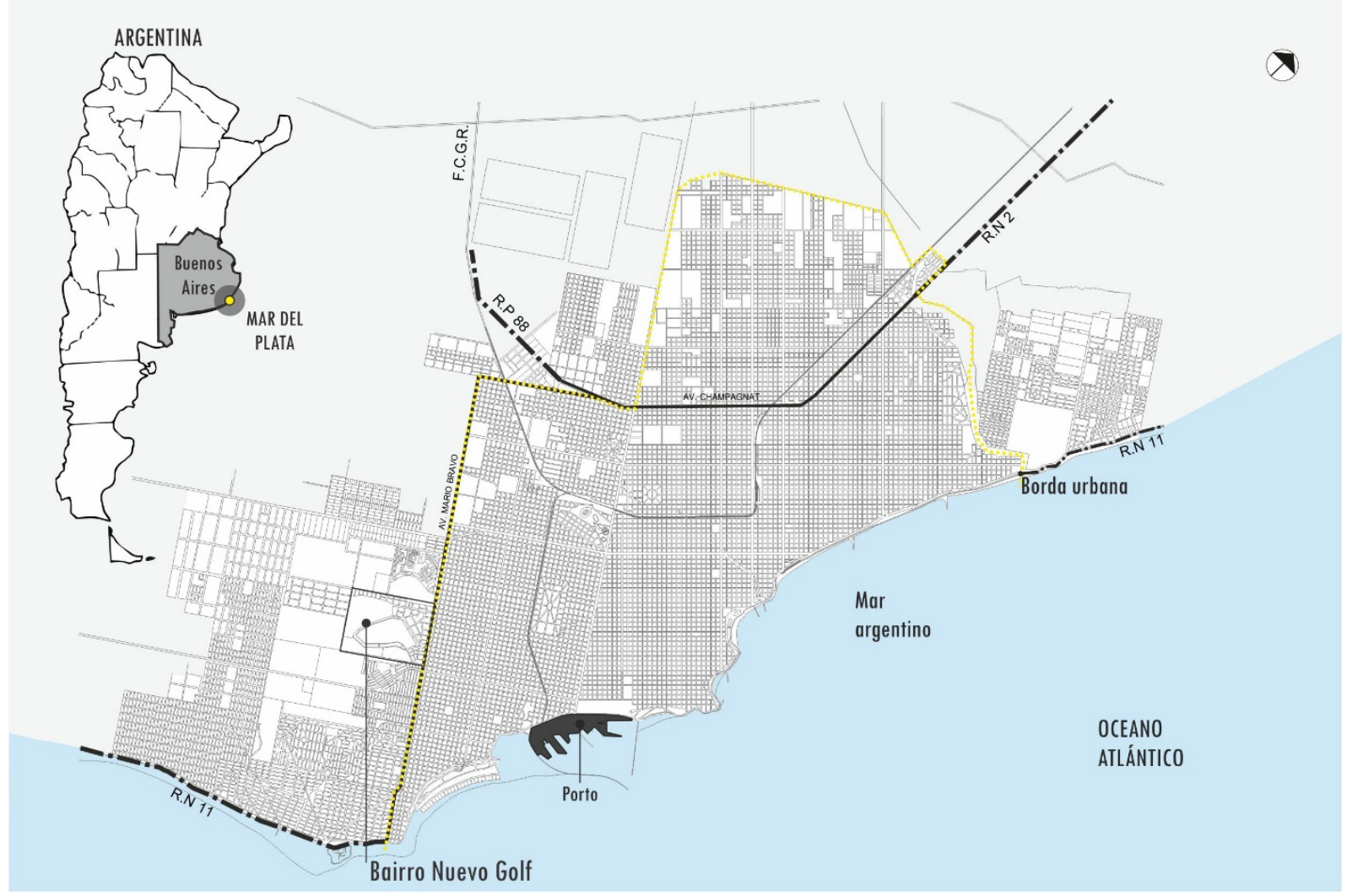

Figura 1 - Localização da cidade de Mar del Plata e do bairro Nuevo Golf. Fonte: elaboração própria, 2018.

O bairro Nuevo Golf surge no marco da "crise de dezembro de 2001", na Argentina, que teve início no final da década de 1990, no contexto de uma longa recessão que desencadeou uma instabilidade humanitária, representativa, social, econômica, financeira e política. A temporalidade da crise, no entanto, abrange mais de duas décadas de aprofundamento da precarização das condições sociais. Isto acarretou, por um lado, altos níveis de desemprego e, por outro, diminuição dos serviços sociais devido à desintegração do chamado Estado de Bem-Estar (Clichevsky, 2000). A natureza estrutural dessa recessão aprofundou as fraturas sociais, a desigualdade e a pobreza, obrigando as famílias a implementar diferentes estratégias de vida para enfrentar novas situações (Rodulfo, 2007).

Ante a falta de acesso à terra e à moradia, imigrantes da região metropolitana de Buenos Aires e províncias do norte argentino ocupam precariamente terras particulares que pertenciam a uma grande família de latifundiários da cidade de Mar del Plata.

0 relevo do bairro, conforme Figura 2, foi uma condicionante para a configuração territorial da ocupação. 0 setor baixo do bairro - próximo à malha urbana consolidada da cidade - foi o primeiro a ser ocupado, como demonstra a imagem de satélite de 2003 (Figura 3). Desde então, o bairro experimentou um crescimento contínuo nesse setor, mais de consolidação do que de ocupação. A partir de 2009, o setor alto iniciou um paulatino processo de ocupação. É importante destacar que a expansão do bairro se encontra condicionada por limites físicos, como os conjuntos habitacionais ou grandes instalações privadas, como Golf Club ao sul-oeste e Rumencó e Arenas del sur ao sul (Figura 2). 


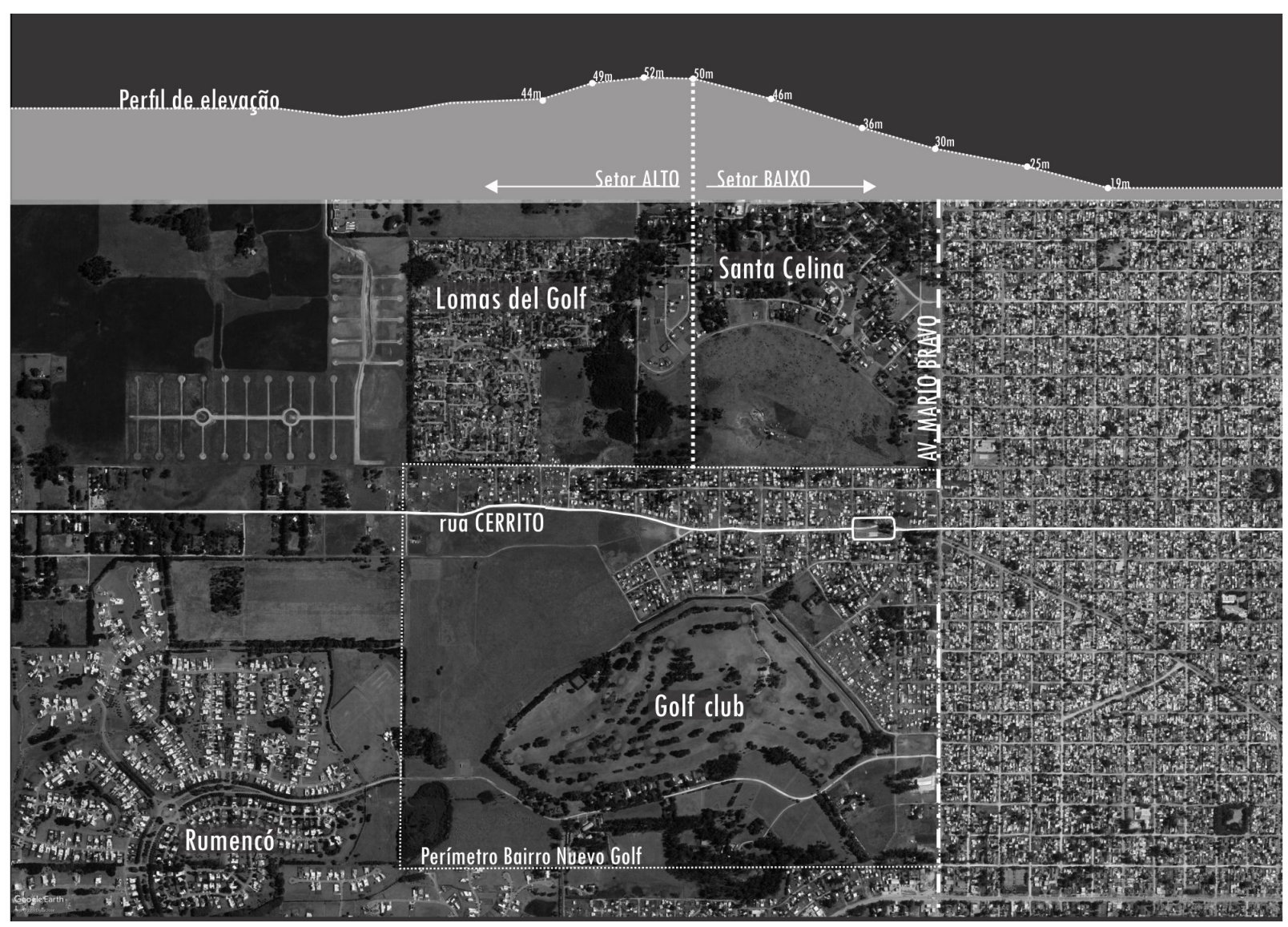

Figura 2 - Localização e relevo do bairro Nuevo Golf. Fonte: elaboração própria, 2019.

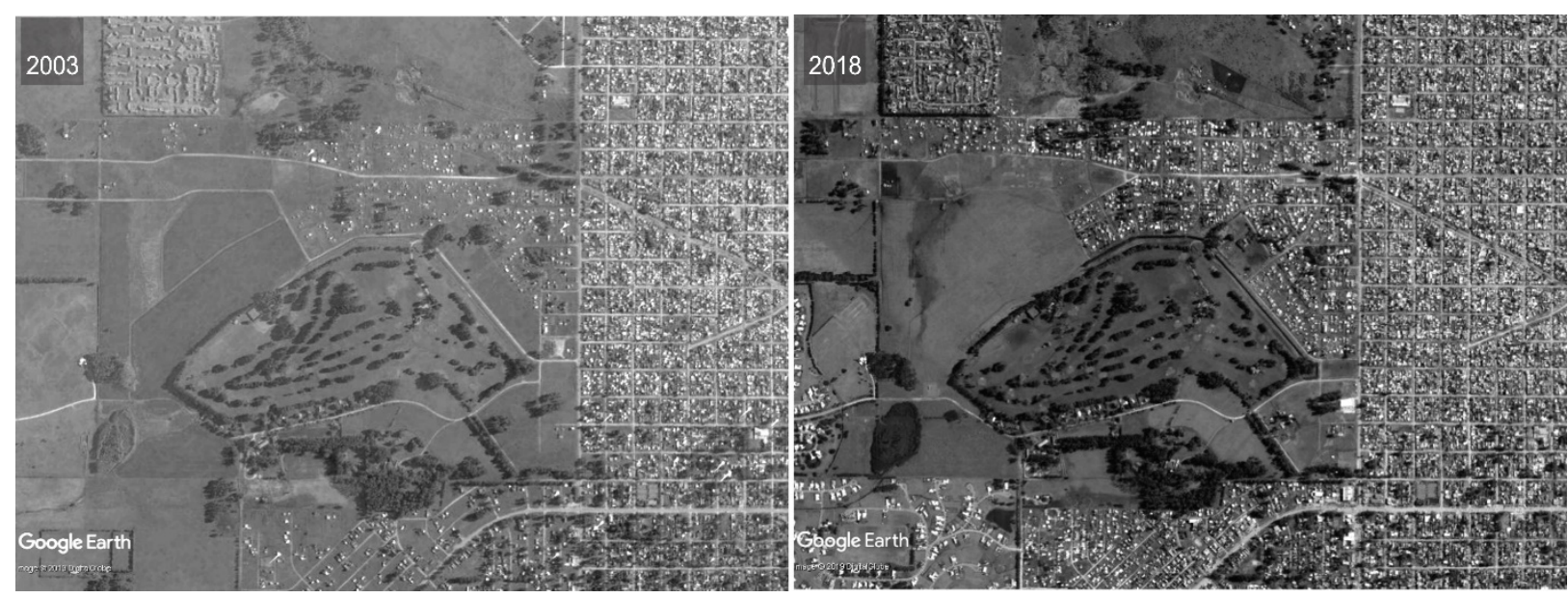

Figura 3 - Transformação da ocupação da área: 2003 e 2018. Fonte: elaboração própria, 2019.

\section{Práticas e atores no processo de urbanização popular}

As práticas e atores que foram sistematizadas neste ponto se manifestam no Nuevo Golf, dentro de um recorte de oito anos: de 2011 a 2018.0 ano que dá início ao recorte marca uma das primeiras reivindicações lideradas pelo presidente da associação de moradores Bairro Nuevo Golf - Mario Peralta - em prol de melhorias urbanas. Isso quer dizer que após uma década da ocupação do Nuevo Golf, iniciada em 2001, as famílias moradoras tomam como referência a sede física da associação de bairro e começam a nuclear atividades. 
Para a sistematização das práticas de urbanização popular, produto da mobilização dos moradores e da construção de alianças com diversos setores para a solução das próprias demandas, foi elaborado um sociograma. Nesse esquema gráfico (Figura 4) se explicitam os atores envolvidos em cada uma das práticas, representados por círculos de diferentes tamanhos e vinculados por linhas. Existem três níveis de atores: ator primário: inicia a prática e continua nela ao longo do seu desenvolvimento; ator secundário: participa da prática com algum tipo de contribuição (econômica, de gestão, humana); ator terciário: participa da prática, mas não é responsável pela sua concretização.

Os atores foram divididos em seis grupos:

1) Estado: identificando entre as ações correspondentes a nação, província e município e, dentro desses subgrupos, os ministérios e secretarias envolvidas;

2) Pesquisa e desenvolvimento $(\mathrm{P}+\mathrm{D})$ : a universidad pertencente a esse grupo é a Universidad Nacional de Mar del Plata (UNMdP), por meio do Programa Hábitat y Ciudadanía, e as diversas faculdades a ele associadas, sendo a Faculdade de Arquitetura, Urbanismo y Diseño (FAUD) a principal. O Consejo Nacional de Investigaciones Científicas y Técnicas (CONICET) é o ente que financia a P+D;

3) Setor privado: aqui se agrupam as empresas prestadoras de serviços e as fornecedoras de matériasprimas e insumos que pertencem à rede de gestão do Programa Hábitat y Ciudadanía;

4) ONGs: a fundação Yo soy porque nosotros somos e as associações civis Supertenedores, Adelante são só algumas das organizações envolvidas, mapeadas para a realização do sociograma;

5) Agrupações-organizações políticas: La trinchera é a organização política que nasce do próprio bairro, os movimentos populares Barrios de pie y La dignidad, no entanto são transcendentes na escala nacional e fazem intervenções pontuais no bairro;

6) Território: o grupo familiar é o primeiro grupo associativo que se diferencia dos moradores no geral por ser este um grupo heterogêneo. Divergências devido à sua heterogeneidade fazem com que nem todos os moradores se envolvam da mesma forma. Por isso, o gráfico representa apenas os moradores envolvidos no melhoramento das suas condições de vida.

Os empreendedores locais se vinculam geralmente aos processos de Tecnologia de Inclusão Social, impulsionados pelo Programa Hábitat y Ciudadanía.

Os refeitórios populares são agentes importantes na dinâmica diária do bairro, já que geralmente se complementam para oferecer comida às crianças ou para dividir leite em pó e outros alimentos aos familiares destas.

O refeitório Dulces Sonrisas (onde hoje funciona uma Casa de Encontro Comunitário), coordenado por Andrea Mansilla, é um dos mais significativos.

A associação de moradores, como comentado, é o principal agente territorial que promove a participação por meio de reuniões para discutir problemas de vizinhança, bem como o desenvolvimento de ideias e projetos para melhoria do bairro. A ação ativista desse espaço está associada às ações militantes do grupo político La Trinchera, ambas lideradas pelo ator relevante, Mario Peralta. 


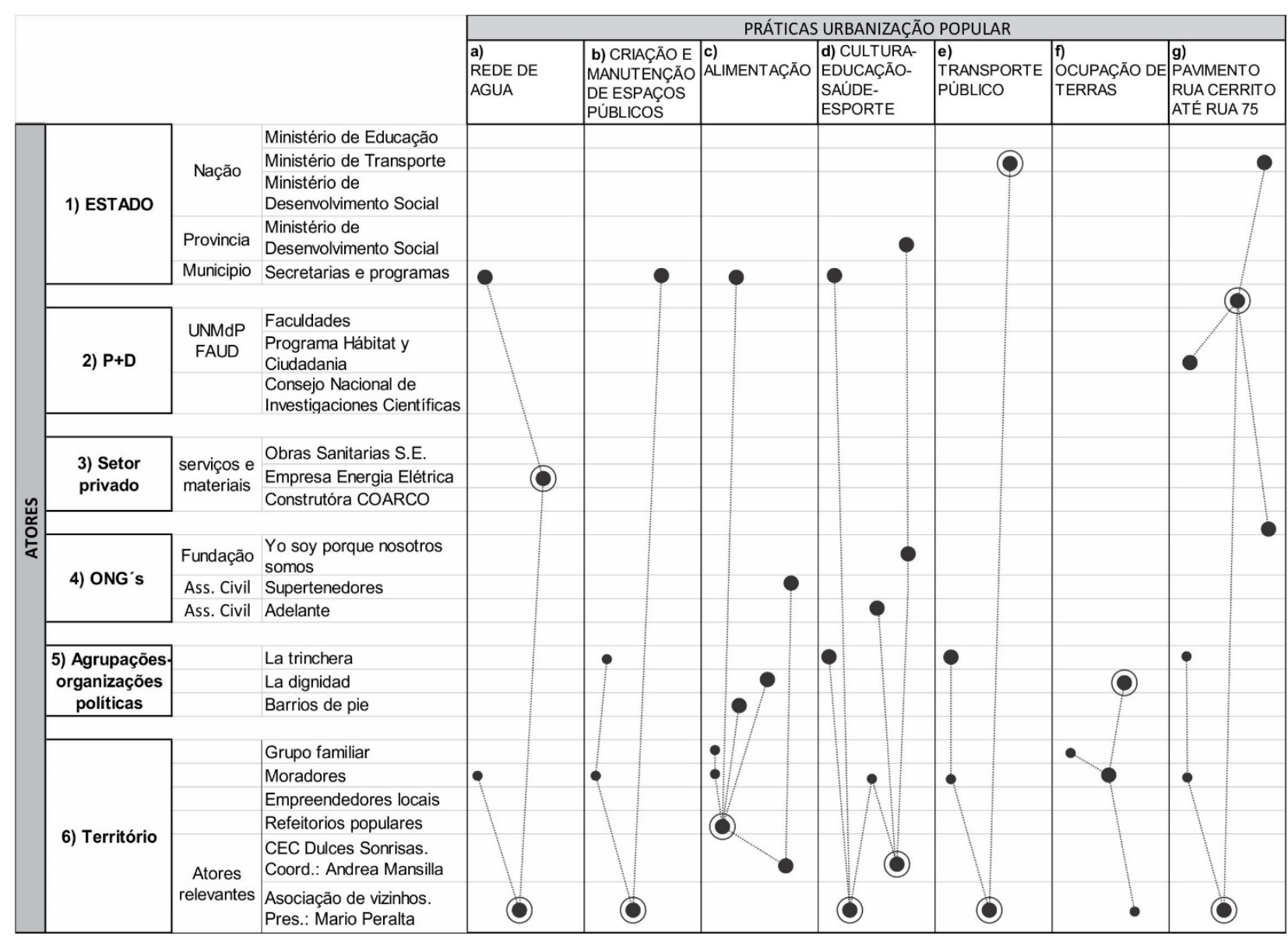

- Ator primário: inicia a prática e continua nela ao longo do seu desenvolvimento

- Ator secundário: participa da prática com algum tipo de contribuição (econômica, de gestão, humana)

- Ator terciário: participa da prática mas não é responsável pela sua concretização

- Vínculos que possiblitaram a concretização das práticas.

Figura 4 - Práticas e atores no processo de urbanização popular do Bairro Nuevo Golf (201 1-2018). Fonte: elaboração própria (2019) com base em Cacopardo et al. (2018).

As práticas que fazem parte do sociograma (Figura 4), detectadas desde 2011, são apresentadas a seguir.

a. Rede de água

Em relação aos serviços urbanos, em infraestrutura e saneamento, existem sérias deficiências na região. Redes de gás e esgoto, por exemplo, são inexistentes. Até 2010, a comunidade não tinha acesso à rede de água - os moradores haviam de encher garrafas na casa de algum morador com bomba de água. Essa situação fez com que a comunidade iniciasse um movimento de luta, fortalecendo sua organização por meio da associação de moradores. A partir disso, houve a ação dos "cortes de rua", na Av. Mario Bravo, via importante na circulação da cidade. Tratava-se de bloqueios para impedir que os carros continuassem circulando, o que gerava um grande conflito. Foi dessa maneira que a luta se tornou visível nos meios de comunicação, o que ajudou na divulgação da problemática que naquele momento atingia 1.200 moradores.

Em 2013, começou a se implementar o Programa "Água mais Trabalho", realizado com a contribuição do Governo Federal por meio do Ministério de Planejamento da Nação, Investimento Público e Serviços, viabilizando um mecanismo de criação de empregos por meio da construção de Cooperativas de Trabalho Sanitário. Concluindo 2013, mais da metade do bairro já contava com água potável. Contudo, as ligações ainda eram muito precárias e o serviço demorou até 2015 para se completar (Figura 5). 


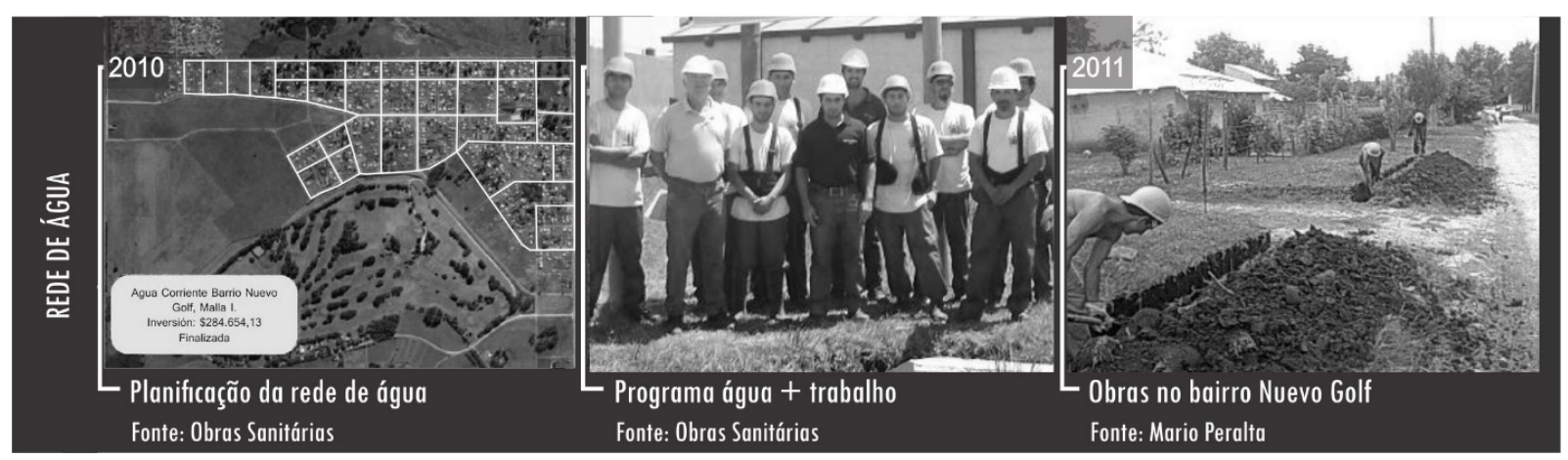

Figura 5 - Rede de água. Fonte: elaboração própria (2019).

b. Criação e manutenção de espaços públicos

A praça pública localizada próxima à Av. Mario Bravo foi sendo paulatinamente apropriada e condicionada a uso, graças ao trabalho da associação de moradores. 0 setor de jogos foi construído com orçamento participativo. Os moradores fizeram uma votação e decidiram colocar uma área de recreação para crianças. A quadra adjacente foi construída por um contingente de estudantes suíços que se encontravam desenvolvendo uma prática comunitária no setor.

A manutenção desses espaços, que deveria ser feita pela prefeitura, é coordenada pelo ator relevante Mario Peralta, quem convoca os moradores para realizar ações que vão de limpeza à construção de equipamento. Nos últimos anos foram realizadas, sistematicamente, ações para que esses espaços pudessem continuar sendo utilizados. Informação verbal de Peralta demonstra a necessidade de trabalhar para a melhora contínua desses espaços tão importantes para o desenvolvimento e o crescimento do bairro e para a qualidade de vida da população.

Cansados das mentiras do município, dizendo que eles iam vir e cortar a grama, mas nunca vieram, saímos com famílias inteiras, homens e mulheres sob um sol que rachava a terra e o calor opressivo do verão para fazer isso sozinhos, mas sem as ferramentas e recursos necessários. Dói ver um Estado ausente, que abandona espaços públicos, especialmente aqueles localizados em bairros pobres, porque nossas humildes crianças que não moram no centro também têm direito a um lugar decente onde possam praticar esportes. Lamentamos que não seja o Estado quem se encarrega, pois é aquele que tem a obrigação, os meios e os recursos para fazê-lo. (Mario Peralta, informação verbal, 2018).

Em 2017, a associação de moradores começa a trabalhar com a Faculdade de Ciências Exatas (UNMdP), da disciplina de Biologia, num projeto de educação ambiental. As atividades começaram como oficinas informativas e educativas e logo se consolidaram com ações concretas no território - como a plantação de árvores nos espaços públicos. 0 levantamento de pontos de lixo no bairro também foi uma das atividades praticadas em conjunto com a associação de moradores, com o objetivo de melhorar a condição de poluições ambiental e visual que estes produzem (Figura 6).

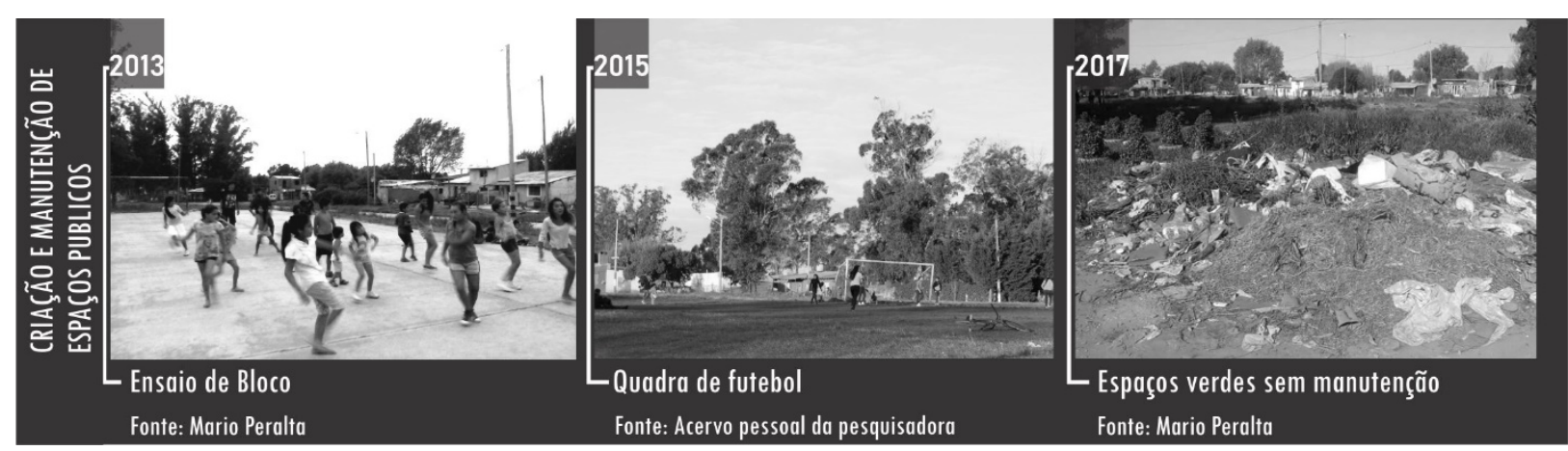

Figura 6 - Criação e manutenção de espaços públicos. Fonte: elaboração própria (2019). 


\section{c. Alimentação}

Uma séria deficiência, alertada pelos profissionais da área da saúde, é a má alimentação na infância, existindo casos tanto de obesidade infantil como de desnutrição. A problemática é abordada por atores relevantes, oferecendo leite ou refeições; alimentos provindos de doações. Para 2018, segundo os dados que forneceu um questionário da Fundação Yo soy porque nosotros somos, havia no bairro oito refeitórios populares.

Ao perguntar à coordenadora do refeitório popular Dulces Sonrisas, Andrea Mansilla, sobre o propósito dessa ação, ela respondeu:

Estamos aqui para ajudar, muitas pessoas passam fome. Já gastei o que ganhei hoje comprando as coisas que faltavam para o lanche, mas me sinto orgulhosa, porque eu fiquei com fome quando criança. Enquanto eu estiver viva, nenhuma outra criança vai passar fome (Andrea Mansilla, entrevista, 2016) (Figura 7).

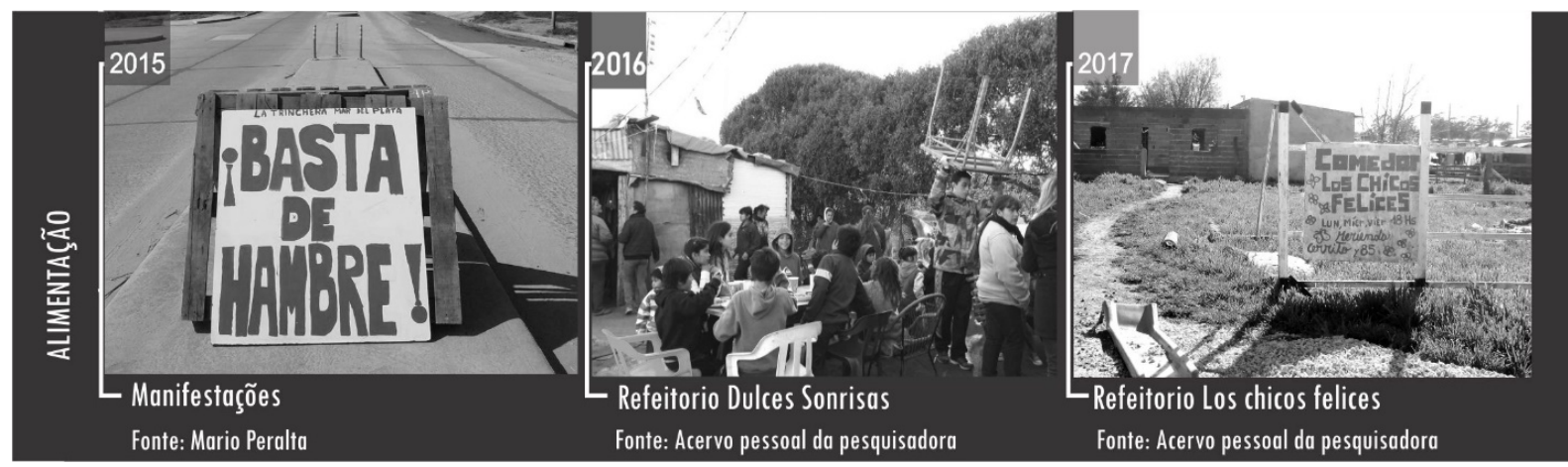

Figura 7. Alimentação. Fonte: elaboração própria (2019).

d. Cultura, educação, saúde e esporte

Diversas atividades são realizadas de modo autogestionário para oferecer cursos e oficinas gratuitas. Outras atividades propostas incluem programas estatais que fazem uso da associação de moradores e da Casa de Encontro Comunitário (CEC) Dulces Sonrisas como ponto de encontro aos habitantes do lugar (Figura 8).

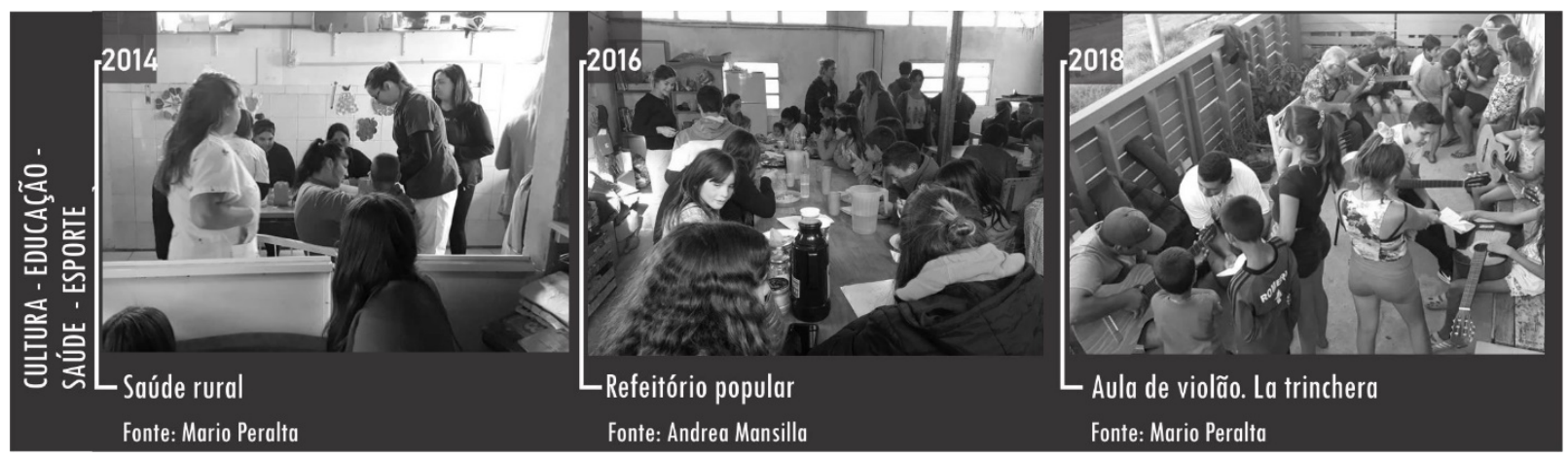

Figura 8 - Cultura, educação, saúde e esporte. Fonte: elaboração própria (2019).

\section{e. Transporte público}

Em 2015, as reivindicações dos moradores por acesso a transporte público foram ouvidas. Com isso, uma linha de ônibus começou a transitar pela rua principal, a Rua Cerrito. No entanto, meses depois da mudança na gestão, os ônibus foram cancelados pela insegurança do bairro, segundo anunciaram os meios de comunicação locais. Em vista dessa situação, os moradores, com o presidente da associação, não cessaram as demandas até conseguir a retomada do serviço. 
Além da necessidade de transporte, os moradores da região também demandam mais segurança, o que inclui iluminação pública e semáforos. Diante desses pedidos, a prefeitura instalou, no mesmo lote onde se localiza a associação de moradores, um posto de segurança policial (Figura 9).

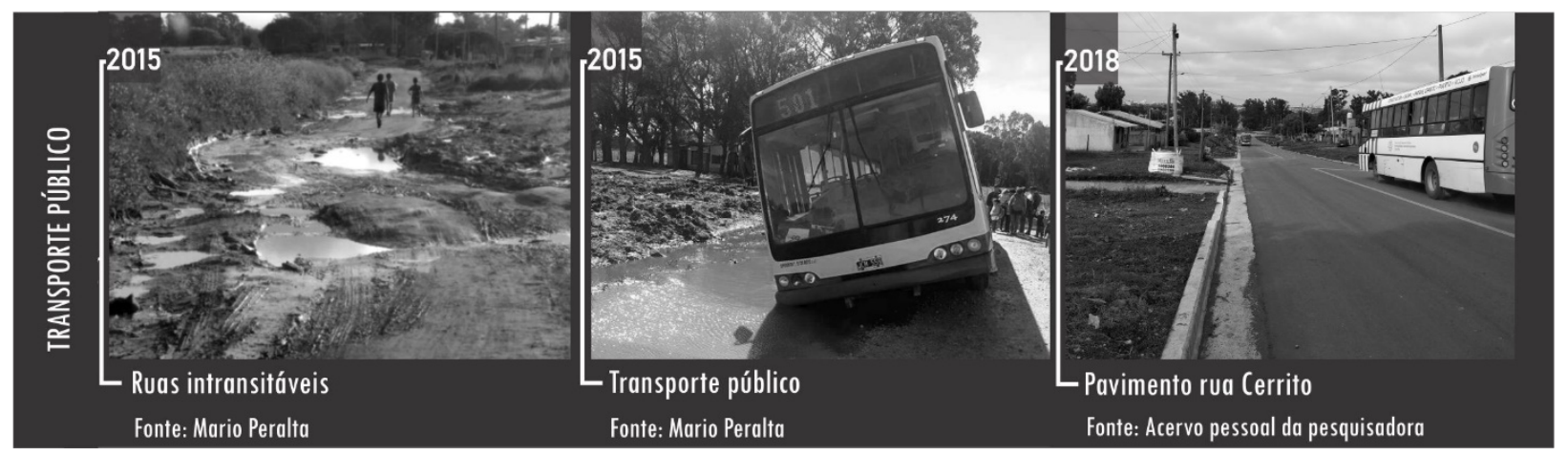

Figura 9 - Transporte público. Fonte: elaboração própria (2019).

\section{f. Ocupação de terras}

Recentemente, em 2018, um novo processo de ocupação de terras teve lugar na parte alta do bairro, em áreas públicas destinadas a equipamentos de uso comunitário e espaços verdes. A ocupação que começou de forma esporádica, dirigida por mulheres que tinham perdido o trabalho, passou a ser organizada pelo movimento popular La Dignidad. 0 movimento, que representava uma pequena parcela de moradores, ocasionou certos conflitos na área. Pois, embora a demanda por habitação fosse legítima, a ocupação de áreas destinadas a equipamentos públicos era vista como prejudicial ao desenvolvimento do bairro. Além disso, em meio ao processo de ocupação, "grileiros" aproveitaram para fazer negócios clandestinos com a comercialização dos lotes ocupados. O desconforto que o presidente da Associação de Moradores demonstrou diante dessa situação se devia ao enfrentamento que estava ocorrendo: de "Pobres contra pobres".

Depois de rodadas de negociação com a entidade de moradores e representantes dos movimentos sociais se chegou ao entendimento de que os lotes que "deveriam" ser ocupados eram somente os privados. 0 dono da área estava disposto a negociar com a prefeitura. Apesar disso, meses depois, as áreas públicas foram ocupadas por mais de 40 famílias que começaram a construir barracos nos lotes anteriormente delimitados por cerca. Diante dessa situação, o presidente da associação de moradores e a agrupação política La trinchera decidiram ocupar uma área para assegurar a futura construção de equipamentos públicos. Uma sede da associação começou a ser construída na área ocupada, servindo para "delimitar território" e como laboratório de experiências de construção sustentável (Figura 10).

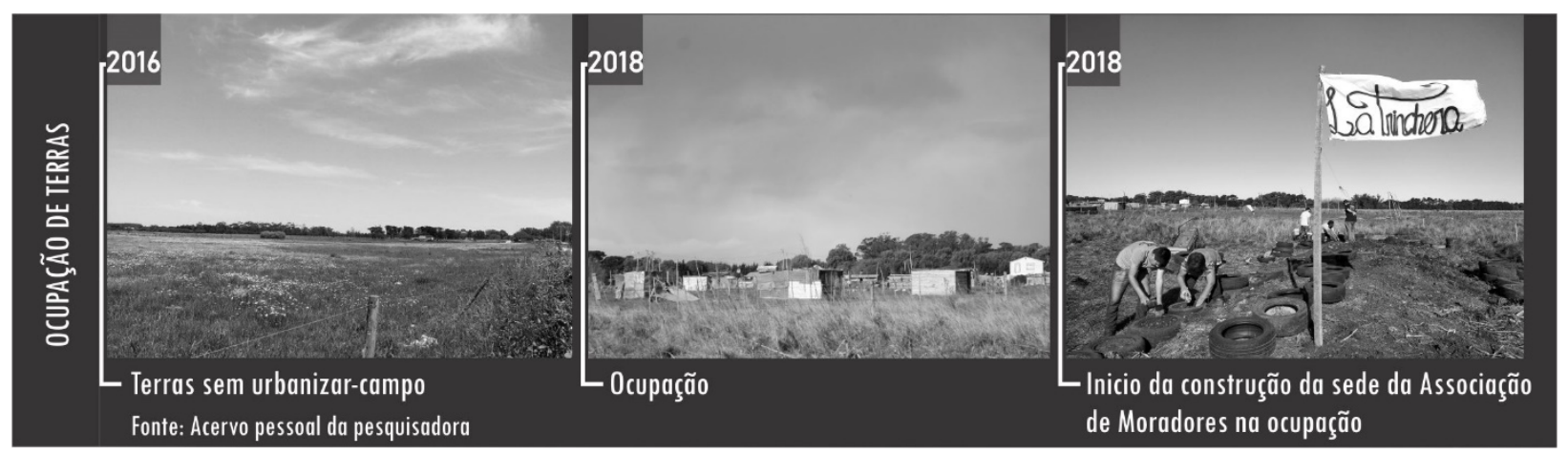

Figura 10 - Ocupação de terras. Fonte: elaboração própria (2019). 


\section{g. Pavimentação da rua Cerrito}

Em 2018, aconteceu uma grande melhora em matéria de serviços. 0 estado intransitável das ruas de lama fez com que os ônibus que estavam transitando desde 2015 fossem impossibilitados de continuar com seu percurso a cada dia de chuva na região. No transcurso de 2017, os vizinhos decidiram retomar as manifestações, fazendo novamente "cortes de rua" para reivindicar ruas acessíveis e iluminação pública na área.

Outro recurso por eles utilizado foi a apresentação de uma nota, denunciando as consequências do corte do serviço, como a impossibilidade de crianças e professores frequentarem a escola, ou o acesso ao hospital, localizado a mais de 30 quadras do bairro. A visibilidade do caso ocorreu quando eles decidiram se amarrar com correntes na porta da prefeitura até alguém receber essa nota assinada pelo presidente da associação, Mário Peralta, e por inumeráveis moradores.

A luta histórica que mantiveram ao longo dos anos resultou na pavimentação de sete quadras da Rua Cerrito, obra que foi iniciada em outubro de 2018. No entanto, a comunidade não se conformou com as sete quadras de pavimento que a obra pública conseguiu fazer. Em novas manifestações, continuaram exigindo que as demais ruas do bairro fossem consertadas e as sete quadras, acondicionadas, para evitar acidentes (Figura 11).

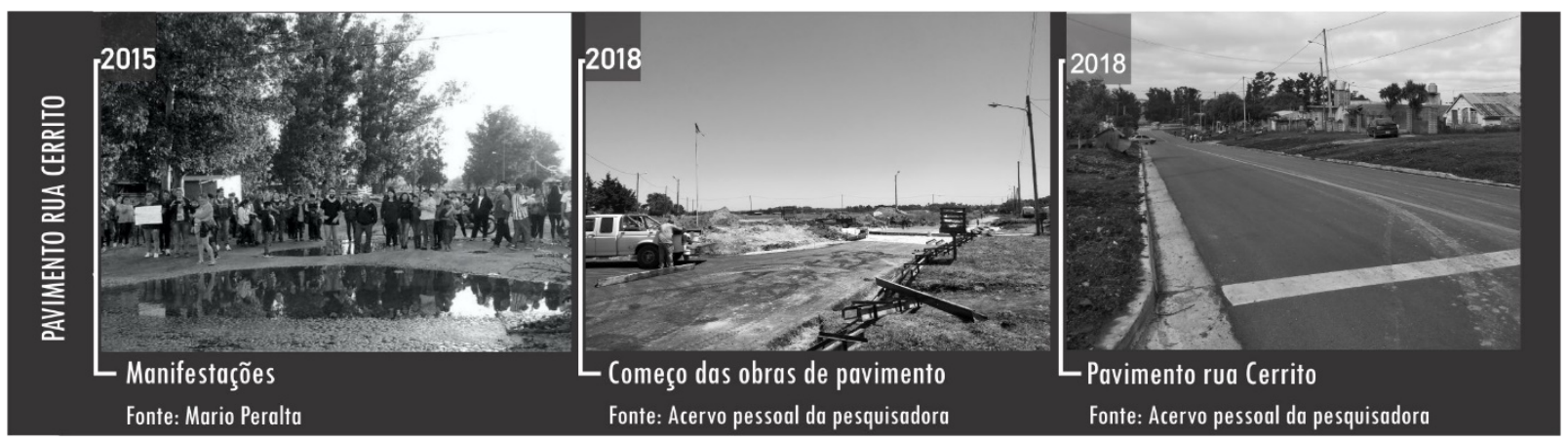

Figura 11 - Pavimentação da rua Cerrito. Fonte: elaboração própria (2019).

Como preâmbulo das considerações finais que serão feitas no próximo ponto, no sociograma apresentado (Figura 4) se observa que o grupo território, por meio de suas manifestações e protestos, gera práticas que urbanizam o bairro Nuevo Golf. Serviços e equipamentos básicos são frequentemente reivindicados ante o agente Estado, que, mediante políticas públicas, programas e projetos, "chega" ao território. Outras necessidades com as quais o Estado não consegue arcar são satisfeitas pelos próprios moradores: alimentação, criação e manutenção de espaços públicos, cultura, educação saúde e esporte. Refeitórios populares, centros comunitários autogeridos e quadras de futebol não são outra coisa senão uma conquista na urbanização desses espaços. Outro exemplo são as ocupações de terras que, perante o déficit de moradia, são "planejadas" por organizações políticas ou bem iniciadas pelos próprios moradores.

Ainda na Figura 4, a representação da interação entre os atores configura um esquema "de baixo para cima", já que na maioria dos casos o grupo território, colocado embaixo, impulsiona os processos. Embora essa alegoria não tenha sido procurada nem intencionada, é sugestiva para pensar em como as estruturas hierárquicas são normalizadas de forma tal que o grupo com "mais poder" fica no topo. São questões que escapam um pouco às intenções desse gráfico, mas que sugerem um questionamento: qual esquema teria se configurado se o grupo território fosse colocado "em cima"? 


\section{Considerações finais}

Na primeira parte deste artigo foi apresentado um panorama amplo das razões pelas quais as periferias são permitidas, incentivadas ou até reguladas nas cidades. A legitimidade das práticas de luta que se manifestam nesses espaços para acessar direitos humanos básicos implica uma forma alternativa de construção de cidade, num jogo de dominação e resistência, ilegalidade e legalidade, exclusão e confronto; dicotomias que acarretam forças políticas insurgentes.

A luta mediante práticas e saberes (outros) para a ruptura do modelo neoliberal pode ser pensada não somente como reivindicações para formar parte dessa cidade "formal", repleta de valores capitalistas, senão como esses contrapoderes que Zibechi (2015) descreve para outra concepção de urbanização. Fica claro que nem todas as lutas podem ser reconhecidas como emancipatórias. No entanto, há lutas muito significativas nesse processo, como as espontaneidades que surgem das próprias necessidades, ou seja, a capacidade de criar soluções de sobrevivência ou desenvolver maneiras de viver em condições e circunstâncias diferentes à dos paradigmas estabelecidos.

Por outro lado, afirmar com base no exposto na segunda parte do artigo que a urbanização popular é "uma conquista" evidencia a identificação de práticas e processos significativos na evolução do bairro. A associação de moradores é o agente que consegue alinhar e coordenar o maior número de atores para a realização de diversas propostas e, dependendo da solução, articula com atores do setor privado ou do setor público. Seu papel político-ativista mobiliza ações de reivindicação de direitos dos cidadãos com uma incrível atitude de resistência, compromisso e luta constante por soluções a problemas locais. 0 sociograma e as sequências de fotos que acompanham o ponto 2 (dois) nos ajudam a visualizar esses processos. As informações verbais dão indício de como os atores relevantes mudam as suas necessidades e perspectivas em benefício da comunidade.

A luta e a resistência são uma questão de sobrevivência, não há que esquecer isso. Mas, ao mesmo tempo, a autonomia que, gradualmente e com muito esforço, os moradores conseguem conquistar possibilita-lhes enxergar suas capacidades, assim como seus direitos, o que acaba "repotencializando" o sentido emancipatório dessas ações. Além da autoconstrução e da autogestão dos serviços urbanos e da auto-organização de atividades culturais, atividades recreativas e esportivas que se organizam idealizam as necessidades e potencialidades desses territórios, pressupondo a construção de uma esfera política que grita forte: "Aqui estamos". Dessa forma, é possível entender a urbanização popular como uma manifestação autônoma, e não um mero preenchimento das lacunas deixadas pela ausência do Estado ou a falta de interesse do capital.

\section{Referências}

Abiko, A., \& Coelho, O. L. (2009) Urbanização de favelas: procedimentos de gestão. In HABITARE. Recomendações técnicas (Vol. 4, 88 p.). Porto Alegre: ANTAC.

Argentina. (2013, 29 de novembro). Lei 14.449 de 29 de novembro de 2013: estabelece o direito à moradia e o hábitat digno e sustentável. Buenos Aires: Boletim oficial.

Brasil. (2001, 10 de julho). Lei 10.257 de 10 de julho de 2001: Regulamenta os artigos 182 e 183 da Constituição Federal, estabelece diretrizes gerais da política urbana e dá outras providências. Brasília: Congresso Nacional.

Cacopardo, F. A., Rotondaro, R., Pepi, M. B., Cacopardo, G., Freire, P., Ispizúa, J., Melián, I., \& Mitidieri, A. (2018).

Tecnologías sociales en territorios urbanos pobres. Revista Redes, 24(47), Recuperado em 12 de setembro de 2017, de https://revistaredes.unq.edu.ar/index.php/redes/article/view/37

Cardoso, A. (2016) Assentamentos precários no Brasil: discutindo conceitos. In M. P. Morais, C. Krause \& V. C. Lima Neto. Caracterização e tipologia de assentamentos precários: estudos de caso brasileiro. Brasilia: IPEA.

Clichevsky, N. (2000) Informalidad y segregación en América Latina. Una aproximación (61 p.). Santiago de Chile: CEPAL. 
Connolly, P. (2013). La ciudad y el hábitat popular: paradigma Latinoamericano. In B. Ramirez \& E. Pradilla (Comp.), Teorías sobre la ciudad en América Latina (pp. 505-562.). México, D.F.: UAM - SITESA.

Costa, H. S. M. (2008). A trajetória temática ambiental no planejamento urbano no Brasil: o encontro de racionalidades distintas. In G. M. Costa \& J. G. Mendonça (Eds.), Planejamento Urbano no Brasil: trajetória, avanços e perspectivas. Belo Horizonte: C/Arte.

Cusicanqui, S. R. (2018). Un mundo Ch'ixi es posible. Ensayos desde un presente em crisis. Buenos Aires: Tinta Limón.

Davis, M. (2006). Planeta Favela. São Paulo: Boitempo.

Denaldi, R. (2013). Planejamento habitacional: notas sobre a precariedade e terra nos Planos locais de habitação (1st ed., 308 p.). São Paulo: Annablume.

Galeano, E. (1998). Patas arriba, La escuela del mundo al revés. Madrid: Siglo XXI.

Habitat International Coalition. (2019). EL CAMINO POSIBLE: producción Social de Hábitat en América Latina. Recuperado em 12 de maio de 2019, de http://hic-gs.org/document.php?pid=4322

Holston, J. (2013). Cidadania Insurgente. Disjunções da democracia e da modernidade no Brasil (488 p.). São Paulo: Companhia das Letras.

Marques, E. (2010) Redes Sociais, segregação e Pobreza. 1.ed, São Paulo: Unesp.

Maricato, E. (2000). As ideias fora do lugar e o lugar fora das ideias. Planejamento urbano no Brasil. In. O.B.F. Arantes, E. Maricato, C. Vainer. A cidade do pensamento único: desmanchando consensos. Rio de Janeiro: Editora Vozes.

Oliveira, F. (2006). 0 vício da virtude. Autoconstrução e acumulação capitalista no Brasil. Novos Estudos CEBRAP, 74, 67-85. https://doi.org/10.1590/S0101-33002006000100005

Pirez, P. (2015). Servicios urbanos y urbanización popular: mercantilización y desmercantilización. In T. Bolivar, M. Rodríguez \& J. M. Erazo. Ciudades en construcción permanente ¿Destino de casas para todos?. (pp. 55-79). Venezuela: CLACSO.

Pirez, P. (2018). Distribución, insolvencia y urbanización popular en América Latina. Revista de Geografía. Espacios, 8(15), 67-93.

Pradilla Cobos, E. (1987). Capital, estado y vivienda en América Latina. México: Fontamara. Recuperado em 12 de setembro de 2017, de http://www.emiliopradillacobos.com/Libros.htm

Rodulfo, M. B. (2007). Políticas habitacionales y producción social del hábitat en la Argentina. In L. D. Salvo, E. Ortecho \& P. Peyloubet (orgs). Ciencia y Tecnologia para el Hábitat Popular: construcción y participación del conocimiento. Compilación de trabajos presentados en el I Seminário Iberoamericano de Ciencia y Tecnología para el Hábitat Popular. Buenos Aires: Nobuko.

Rolnik, R. (2015). Guerra dos lugares. A colonização da terra e da moradia na era das finanças. São Paulo: Boitempo.

Roy, A. (2005). Urban informality: toward an epistemology of planning. Journal of the American Planning Association, 71(2), 147-158. http://dx.doi.org/10.1080/01944360508976689.

Zibechi, R. (2006) La emancipación como producción de vínculos. In A. E. Ceceña (Comp.), Los desafíos de las emancipaciones en un contexto militarizado (pp. 123-149). Ciudad Autónoma de Buenos Aires: CLACSO.

Zibechi, R. (2015). Territórios em resistência. Cartografia política das periferias urbanas latino-americanas. Rio de Janeiro: Consequência.

Editor: Rodrigo Firmino

Recebido: Out. 12, 2019

Aprovado: Mar. 20, 2020 